\title{
The Evolution of Pastoral Care Ministry through the Ages
}

\author{
Xolisa Jibiliza \\ Centre for Theology and Religion \\ University of Fort Hare, South Africa \\ E-mail: xjibiliza@yahoo.com \\ DOI: https://doi.org/10.46222/pharosjot.10211
}

\section{Introduction}

People are commanded by Jesus to love one another as he loved us (John 13:34). We are called to be conduits of God's grace to others in our community. Christ's love for us should motivate us to love others in response. Pastoral care is then intentional Christian care for others. It derives from God and its goal is that people might experience not only human care but God's infinite love for humanity. The pastor, priest or minister plays a very decisive role in feeding the church not only spiritually as its shepherd, but also by providing the essential leadership and direction necessary for the church to achieve its chief mission and directive. Pastoral care and counseling represent a means by which the shepherd and leader of the church fulfills his spiritual and social responsibility to the church. Pastoral care and counseling are the needed ingredients in the life of the church. When these are absent, no real tie between the church leadership and parishioners can exist. Pastoral counseling and care are needed to tackle a myriad of challenges members face. This brief research paper sought to acknowledge the historical evolution of pastoral care ministry through the ages. The paper revealed the following themes: definition of what evolution is, an explanation of the notion of pastoral care, what students think about pastoral care, and it ultimately leads to a conclusion on pastoral care. Furthermore, this paper sought to give an impact of the notion of pastoral care to the lives of church members. This paper also revealed the origins and features of pastoral care ministry in the New Testament era. Furthermore the evolution of pastoral care is briefly addressed through a range of historical factors of the church. The functions of pastoral care are also discussed to an extent. Lastly, some dimensions and aims of pastoral care are also addressed.

Keywords: Evolution, pastoral care, healing, reconciliation and reformation.

\section{Introduction: The Biblical Origins of the Pastoral Ministry New Testament}

Pastoral care is a modern term for an ancient archetype of emotional, social and spiritual support that can be found in all cultures and traditions. The term is considered all-encompassing of markedly non-religious forms of support, as well as support for people from religious communities in a Christian setting as well as in other faiths. The New Testament (NT) builds on the Old Testament (OT) foundation of pastoral care as it reveals the Chief Shepherd, Christ, in all His wisdom, glory, power, and humility (John 10:11, 14; 1 Peter 5:4). The person and work of the Great Shepherd was concluded by His death and His resurrection (Hebrews 13:20; 1 Peter 2:25). John 10:11-16 stated that the Good Shepherd gave His life for His sheep that He calls to Himself. Also Jesus stated that $\mathrm{He}$ also has other sheep who do not conform or belong to his flock. Nonetheless care of people is a concern and pastoral care covers many functions relating to spiritual health, counseling and education. A pastoral caregiver is thus somebody who focuses on providing spiritual support services like counseling, visitations to hospitals or prisons, palliative 
and bereavement care, prayer sessions and memorial services (Arnold, 2012; Nouwen, 2006). The term 'pastor' as used in this study, also relates to terms in diverse denominations such as priest or minister of religion.

\section{Biblical Distinguishing Features of the Pastoral Office in the New Testament}

There five different terms in the New Testament referring to the pastoral office:

$>$ Elder (presbyter)- this title stresses the administration and spiritual guidance of the church (Acts 15:6; 1 Timothy. 5:17; Jas. 5:14; 1 Peter 5:1-4);

$>$ Bishop or overseer (Episkopos) - which places emphasis on guidance, oversight, and leadership in the church (Acts 20:28; Philemon 1:1; 1 Timothy 3:2-5; Titus 1:7);

$>$ Shepherd or pastor - is an office indicating leadership and authority (Acts 20:28-31; Ephesians 4:11) and also guidance and provision (1 Peter 5:2-3; cf. 2:25);

$>$ Preacher - one who publicly proclaims the gospel and teaching to the flock (Romans $10: 14 ; 1$ Timothy $2: 7 ; 2$ Timothy $1: 11$ ); and finally,

$>$ Teacher - one who is accountable for training and description for the Scriptures.

\section{Definition of Evolution}

Evolution is change in the heritable qualities of organic populaces over progressive ages or the gradual development of something. Cartright (1953: 4) argued that the scientific theory of evolution by natural selection was proposed by Charles Darwin and Alfred Russell Wallace in the mid-19th century and was set out in detail in Darwin's book On the Origin of Species. Furthermore Cartright (1953: 5) stresses that evolution by natural selection was first shown by the perception that more posterity is frequently delivered than can be endured. Thus, evolution literally means relating to the improvement of something over a long period of time, with a context and diverse content of things being affected.

\section{Pastoral Care}

Pastoral care refers to a form of support that addresses the emotional, spiritual, and sometimes physical needs of the person receiving help. Historically, it has been provided by a trained member of religious clergy and is based on biblical teachings and principles. Ungvarsky (2018: 2) said that the word pastoral comes from the Latin word pastor which meaning "shepherd," and pastoralis, meaning "pertaining to a shepherd." Furthermore he states that the common idea of pastoral care is derived from the Christian image of Jesus Christ as a shepherd tending to a flock of followers. Just as sheep are dependent on the shepherd to help them deal with any difficulties or dangers they encounter, Christian theology holds that Christ's followers should turn to him as their main source of help.

Pastoral care is that aspect of the ministry of the church which is concerned with the well-being of the individual and of the community in general (Campbell, 1987: 188). Moreover, it is not only the role of a pastor but also that of a layperson who should also participate in that kind of a ministry. Ungvarsky (2018: 2) argued that in some cases, pastoral care can also refer to assistance provided through hospital or school counselors when this treatment embraces the inkling that pastoral care should address more than just the person's psychological needs and wants.

Jaeckie and Clebsch (1975: 4) stated that pastoral care is the ministry of the cure of souls that consist in helping acts, done by representatives of Christian bodies and persons, directed toward the healing, sustaining, guiding and reconciling of troubled persons whose troubles arise in the 
context of decisive meanings and concerns. Therefore the writer opines that pastoral care forms a vital part of theological teachings.

Gerkin stresses that pastoral care is what is done in the shepherding model (Gerkin, 1997: 113). Gerkin's biblical traditional method of 'shepherding' involves the trialogical structure of priests, prophets, wise men and women and is based on an understanding of the way in which these individuals collectively took authority for shepherding of God's people or the Laos tou Theou in the Old Testament (Nicolaides, 2010).

Gerkin's approach focuses both on individual and family needs. He points out that pastoral care involves both the care of the Christian community and the care of persons: individually, in families, and in large group relationship (1997: 113). This is in contrast to the psychotherapeutic pastoral care model that is foremost and common in America and Western pastoral care thinking. Gerkin's approach to pastoral care has been advanced by many African scholars. For example, Tapiwa Mucherera has argued that therapy or counseling as taught in the West will not always suffice in indigenous contexts since these theories tend to promote and focus on individuality, autonomy and independence (Mucherera, 2009: ix). This caring method of shepherding was helpful because it provided an integrated approach to healing that was enculturated in the African belief system and culture, such as ubuntu (Nicolaides, 2005), which views healing as taking place within the community and not in isolation. Gerkin (1997: 80) illustrated his point by stating that "the depiction of Jesus as the good shepherd who knows his sheep and is known by his sheep, has painted a meaningful, normative portrait of the pastor of God's people". Community also encompasses unity with the people of God, that is, the total body of Christ and ubuntu expresses the truth that people need each other, and this it parallels with what community and care is stated as in the New Testament (Nicolaides, 2005). "From a Christian perspective there are many connections with ubuntu that can be explored to refine the wonderful social values that are part of the culture of ubuntu" (Breed \& Semenya, 2015).

The researcher of this paper has observed that pastoral care aims to address individual and family problems within the context of lived experiences. Thus, this is an ideal method of helping people who are in need of pastoral care/therapy and this includes mothers affected by child defilement by a church leader (Gerkin, 1997: 81) and many other things.

Pastoral care of the church as a group should begin by observing and attempting to understand the inner, subjective experiences of the church's self as a koinonia (community). Pastoral care can also help people fix relationships by teaching them ways to forgive and reconcile. Another function of pastoral care is helping and controlling an individual to settle on decisions that are situated in the greater good and virtuous moral standards, frequently utilizing confidence as a rule. In some cases, this includes teaching and training an individual to frame relationships dependent on appreciation, thoughtfulness, tolerance, and diverse qualities.

Hulme (1981: 8) defines pastoral care as the supporting ministry of the church to people and those close to the church that are experiencing the familiar trials that characterize life in this world, such as illness and the Covid-19 pandemic and other diseases, surgery, incapacitation, death and bereavement. Hulme's argument about pastoral care entails and agrees with the example of the biblical story of Job. Sifo (Ref: conversation in class, 28/02/2019) gave an example of Job's friends visit to Job as being part of pastoral care. Pastoral care is designated for many ministries such as preaching, administration the sacraments, pastoral administration, teaching and other nurturing ministries. Hulme (1981: 10) argued that these ministries are furthermore implicitly and explicitly dialogical, moreover the variation is a matter of emphasis. 
Sifo (2014: 5) understood that pastoral care is the healing ministry that ought to bring healing to the victims that are wounded. The writer of this assignment observed that pastoral care emphasizes church members' everyday lives and requires people to fulfill their potential in all areas. Therefore people should acquire what is needed for them. Pastoral care is that provision of well-being and protection of a shepherd to take the responsibility of a local authority and to look after the flock with care and solemn attention to avoid destruction. Campbell (1987: 188) stated that Clebsch and Jaekle in their study of pastoral care through the ages identified four pastoral functions which are: healing, guiding, sustaining and reconciliation. The writer of this study thus opted for the pastoral care functions.

\section{Pastoral care function}

Each function of pastoral care is essential for the curing of souls. These functions are limited to the work of pastoral care within its confinements. The researcher decided on healing as the first function to present.

\section{a) The pastoral care function of healing}

The pastoral care function of healing having stressed the fact that there is need for church-wide enlightenment and proper counseling, this section is known as the curative or healing approach. Jaeckie and Clebsch (1975: 8) argued that healing is that function in which a representative Christian person helps a debilitated person to be restored to a condition of wholeness, on the assumption that this restoration achieves also a new level of spiritual insight and welfare. Pastoral healing therefore, is to separate a person from illness that means a healing of totality that includes mind, soul, and body. Furthermore, pastoral healing may proceed with the solicitation of curing that brings a person looking for the healing to a point of wellness.

There is a need for promptness in the pastoral care function of healing, effectual prayer, and appropriate referral. There are however, many different views about healing. Furthermost healing from a theological point of view, focuses on curing the soul of a person. Jaeckie and Clebsch (1975: 8) argued that pastoral healing cures advancements in the soul's ability to figure out on illness and health issues.

Louw (2011: 4a) agreed that the pastoral care function of healing is a vehicle or tool to bring about a profound transformation of the individual's mode of seeing and being, a transformation of one's vision of the world and a transformation of human intentionality. The person being healed must become transformed in his/her life..

Moreover, Louw (2011 4b), stated that healing helps to identify a gap between a person's actual way of life and any potential ways of life that could foster hope and encourage one to take responsible decisions. Therefore the mind is included in a process of healing.

\section{b) Pastoral care function of sustaining}

The function of sustaining is another pillar supporting pastoral care to have its stand as a discipline. Sustaining consists of helping a hurting person to sustain him or herself under the circumstances whereby the person is restored to their former condition (Jaeckie and Clebsch, 1975: 8). This function of sustaining should contain the aspect of compassion as it deals with the empirical methodologies such as bereavement etc. Furthermore this aspect should achieve the spirituality on its growth. This kind of a ministry is more emphasized when someone has been lost a member of his/her family. 


\section{c) Pastoral care function of guiding}

This function provides and consists of helping people to make the right decision makings at the right time. Thus, Jaeckie and Clebsch (1975: 9) stated that the pastoral function of guiding has the characteristic of assisting others to make good decisions under-pressure even though the decisions affect the present and future state of the soul. Moreover, Jaeckie and Clebsch (1975: 9) stated that this function employed two models which are: Educative and Inductive guidance.

- Educative guidance tends to draw out the individual's own experiences and values the criteria and resource for decisions.

- Inductive guidance tends to lead individuals to adopt a prior set of values and criteria by which they make a decision.

The educative guidance aspect is based on the experiences and values for a person to take a decision while the inductive is based on theory. Furthermore perhaps the most familiar modern form of educative guidance is known as client-centered therapy while the inductive guidance classical approach appeals to the long tradition of Christian moral theology and justification.

\section{d) Pastoral care function of reconciliation}

The good relationship between a human being and his/her fellow human beings and between God and man was broken at the 'fall'. Jaeckie and Clebsch (1975: 9) stress that the function of reconciliation seeks to re-establish a broken relationship between man and fellow man and also between man and God. This function used to employ the role of forgiveness and discipline and restore the right relationship with God. Forgiveness is the ministry of curing the souls that has been greatly developed. Reconciliation takes place through forgiveness which can be a proclamation and re-uniting of persons or groups (Jaeckie \& Clebsch, 1975: 9). Moreover discipline is a mode that is concerned with confession and the amendment of one's life.

\section{Dimensions of pastoral care}

Sifo (class notes 28 January 2019) said that there are four pastoral care dimensions. The first one, refers to the question that every pastoral caregiver will have to answer to the congregation concerning both the content and quality of the prospective pastoral relationship. He continued to highlight that the second dimension of pastoral care in the parish consists of a complex set of relationships between the pastor and the congregation. A good pastoral caregiver will make sure that life-giving relationships are nurtured at all these levels (SMMS 2019 Notes). On the third dimension Sifo (class notes 28 January 2019) argued that when pastors enter into ministry in a particular place, they become part of a story of life and ministry that has been going on long before their arrival. Sifo said that the fourth and last dimension should be the response of the pastor to requests, questions and concerns from the congregation and it should be founded on a clearly understood and articulated theology of the church and of ministry.

\section{Aims of Pastoral Care}

\section{a) Pastoral care and morality}

A pastor is the caretaker of the moral lives of the people because they are called to give pastoral care to God's people. 


\section{b) Pastoral care and spiritual life}

A pastor's role is also to offer spiritual direction, discernment, mentorship and guidance. All church members see pastors as the anointed one of God who leads them spiritually.

\section{c) Pastoral care and listening to God's people}

Pastors should listen and be attentive to the psychodynamics and the inner life of the people entrusted to their care.

\section{d) Pastoral care for those in special need}

Pastoral care is about making available to all those in need the loving touch and transforming care of God.

e) Pastoral concern for persons and their and other social situations and conditions.

Pastoral care is a ministry of social and cultural transformation.

\section{The Evolution of Pastoral Care through the Ages}

The evolution of pastoral care has been developed through the centuries. Pastoral care evolved from the early church during the period of apostolic fathers, in the post-Constantinian period, the Middle Ages, the Reformation Age, the Evangelical Revival, the 20th century and beyond. It has undergone diverse patterns and approaches in its evolution and new directions in pastoral care.

\section{a) The post-Apostolic period [the early church]}

In the early Church years of pastoral care the apostolic fathers who were the successors of the apostles suggested an increasing separation between the clergy and the laity. Furthermore, there was stress on the need to obey clergy therefore they emphasized that pastoral care should be the work of clergy (Tidball, 2009: 148). All pastoral work was the entitlement of the clergy and the work of the bishops, who all practiced pastoral care.

The Early Church fathers reveal that a three-fold ministry of bishops, priests and deacon is not the only existence, nonetheless it was the essence of the Church (Tidball, 2009:148). The work of the clergy ought to be humanistic in orientation, with liberal feelings for a wide sympathy for all individuals. During that time the people that were in the public eye for pastoral care were the widows, orphans and those who were in need due to their social circumstances. Widows were regarded as the most impoverished people who needed to 'take a journey' with pastoral caregivers and orphans. Tidball (2009: 149) stresses that it was their business to recover the drifters and to look after all who were ill, and to never disregard the widow, the orphans and the needy. Their pastoral caring was in honour of the almighty God. During the time of the postapostolic period the presbyters understood that power was conferred to the bishops by God and they were to be followed by other ministers and the congregation like 'sheep following the shepherd' (Tidball, 2009:148). The bishops were the chief pastors that were tasked with leading the pastoral caring ministry as they became the 'pastors to the pastors'. The duties of the shepherd were to take care of the flock and they received a credit from the supreme shepherd who is Jesus Himself. The principal duty of a shepherd in a pastoral care was to thus embrace love that is unconditional for everyone. Tidball (2009: 52) stated that God was at one and same time impressing the notion that the discipline of loving each other and condemning sin is important. Therefore love (agape)is central to the pastoral care ministry. 


\section{b) The Post-Constantinian Period}

Tidball (2009: 153a) stated that in 312CE the emperor Constantine converted due to his mother Helen's endeavours, and the Christian faith was now tolerated and became the official faith of the state in his empire. Even though this system had its disadvantages because the Christian faith was used for state benefits, it nonetheless contained a new epistemological trend of pastoral care. Tidball (2009: 153b) argued that although some factors, such as the threat of heresy, remained constant the new situation called for a reorientation of pastoral care because the church was still composed of members who faced persecution at that time. Pastoral care was much in demand due to challenges like posed in society usch as inter-alia, homeless people, orphans and those who are needy, as they had no place or sense of belonging.

The period of Constantine up to the early ages of the mediaeval era produced pastoral care writings which reflected in a detailed and self-conscious manner, the skills a pastoral care giver required and the standards he was expected to reach in his task (Tidball, 2009: 153). Furthermore pastoring people was considered to be a harder job than guiding a 'flock of sheep'. The PostConstantinian era uncovered that pastoral care is indeed an aspect of caring a pastoral caregiver has to carry burdens of the people of God (Laos tou Theou) (Nicolaides, 2010). Moreover, it was accepted that the office of shepherding placed power upon the pastor and person's 'holiness' could be helpful in this work of God (Tidball, 2009: 164).

\section{c) The Middle Ages}

During the Early Medieval Period, Pope Gregory the Great (540-604 CE) was renowned for his administrative competence and ecclesiastical reforms during a time of "obscurantism, superstition, and credulity" (Gonzalez, 288). Gregory helped to solidify the Christian church as a support of European society for many centuries to follow (Hiestand \& Wilson, 2015).

Pope Gregory equipped the clergy to enter the Middle Ages well with what was the great pastoral care rule. Thus, he not only spread the seed for a fruitful pastoral ministry, but furthermore also spread the seeds of ministerial decay due to some abuses manifesting (Tidball, 2009: 171). One of Pope Gregory's most celebrated literary works is the treatise, Pastoral Care (Liber Regulae Pastoralis), which was a four-book elucidation that offered archetypal guidelines for priests and bishops on how to wisely and biblically lead their flock, (the churches) and how to ethically manage their lives. Gregory presented his papal judgement on the credentials, attitudes, choices, and actions of being a truly good pastor, or, 'physician of the heart.' (Book I, Ch. 2).

For Gregory, a pastor existed for the advantage of his flock, and not the reverse, which he saw happening on a regular basis in mediaeval society (Moorehead, 2005). Pastoral care was at the center and very heart of the ministry of the clergy even though there were lay persons who practiced a pastoral care ministry. The pastoral practitioner had to be conscientious in their practice to look after the people of God at all times. Tidball (2009: 174b) said that the shepherds of the flock must be diligent in their pastoral care in which 'diseases' do not attack their flock easily. The duties of the shepherd are then to take care of the flock, looking for the 'green pastures for the flock', driving the flock to drink water and protect them from the wild beasts that surround them (St. Gregory the Great, 2012). Sifo (conversation in class 03/02/2019) stated that sheep knew their shepherd's whistle, and his voice as a shepherd who worked with his/her sheep on daily basis. The shepherd should be willing to suffer for his flock and to protect them as best he could. Gregory asserted that the pastor was still filled with the same corrupted nature as the parishioners. This then necessitated great self-awareness and self-reflection on their part so that the pastor's activities were accomplished out of sincere love of neighbor rather than the pastor's rather than self - aggrandisement. Gregory stated: 
That they should first shake themselves up by lofty deeds, and then make others solicitous for good living; that they should first smite themselves with the wings of their thoughts; that whatsoever in themselves is unprofitably torpid they should discover by anxious investigation, and correct by strict animadversion, and then at length set in order the life of others by speaking; that they should take heed to punish their own faults by bewailings, and then denounce what calls for punishment in others; and that, before they give voice to words of exhortation, they should proclaim in their deeds all that they are about to speak. (Book III, Ch. 40.)

\section{d) The Reformation Age}

The Reformation was not only about ideas bust was also about appropriately understanding the gospel for the good of people and the salvation of all souls.

Tidball in his argument about the Reformation Age and the evolution of pastoral care used the views of Martin Luther a German theologian, Martin Bucer, Ulrich Zwingli a Swiss theologian and reformer, John Calvin, and Richard Baxter, and all of them left a legacy between $15^{\text {th }}$ and $17^{\text {th }}$ centuries (Tidball 2009: 179-201).

The Reformation was a diverse movement. But at its center was a pulsing, yearning concern for the well-being of souls. Its leaders were pastors at pains to lead their flock—and others from around the world-to forgiveness before God and the resultant living hope, the knowledge of God's care and presence in the real hardships of this world and the certain hope of resurrection (Themelios, n.d.)

During the period of Martin Luther they understood that a ministry of the church is the ministry of the world and the pastor became the teacher of the flock (Tidball 2009: 180). Pastoral care in its form was to encourage people to believe in God's word using tools like preaching, visiting the sick, praying for those who were in need of prayers, caring for those who need care etc. and for all those who are 'down in their spirits' the pastoral care practitioner should strive to help them. Furthermore Tidball (2009:180) stresses that pastoral care took the form of application of the word of God to the needs of the people and the encouragement of the people of God to have faith to the word. Luther said of pastors:

Men who hold the office of the ministry should have the heart of a mother toward the church; for if they have no such heart, they soon become lazy and disgusted, and suffering, in particular, will find them unwilling. ... Unless your heart toward the sheep is like that of a mother toward her children-a mother, who walks through fire to save her children-you will not be fit to be a preacher. Labor, work, un-thankfulness, hatred, envy, and all kinds of sufferings will meet you in this office. If, then, the mother heart, the great love, is not there to drive the preachers, the sheep will be poorly served. (Martin Luther, 1994).

During the time of Martin Bucer many reformers made some contribution to a renewed understanding of pastoral care in the Church (Tidball, 2009: 183). Bucer calls for serious, enthusiastic evangelistic work. To pastors he said, "....true carers' of souls and faithful ministers of Christ are not to miss anyone anywhere out with the word of salvation, but diligently to endeavor to seek out all those to whom they may have access in order to lead them to Christ our Lord" (Bucer, 2009). 
In addition Tidball (2009: 184) stated that Zwingli who had a great career, from about 1519 to $1529 \mathrm{CE}$, stresses the need for pastors to be on guard over their sheep so as to prevent them from falling into illness or danger and he saw pastors as a 'gift from God' for the protection of the flock and suggested that the sheep were never so healthy as when they were fed on the 'pure word of God' without a human addition to it. Pastors live in-between their communities and therefore know the human weaknesses of people and thus they should strengthen them and come up with the solutions for the problems beset them. . Zwingli, believed the foundation of theology is the Holy Bible. Zwingli used scripture continuously in his writings. He placed its authority above other sources such as the ecumenical councils or the Early Church Fathers. The principles that directed Zwingli's interpretations are derivatives from his rationalist humanist education and his Reformed understanding of the Bible (Stephens, 1986).

The Reformed Pastor, a work by the English Puritan Richard Baxter, is one of the most accommodating works available on the theme of pastoral ministry and especially these days when there is so much misperception over pastoral roles and expectations.

Baxter found himself having to choose between two unworkable options: he could either begin the process of identifying, admonishing and if necessary, banning all the impenitent sinners within the parish communion or he could continue as before and forebear the practice parish of the parish discipline (Black, 2001: 662). His work The Reformed Pastor is an protracted treatment of the book of Acts 20:28: "Take heed therefore unto yourselves, and to all the flock, over which the Holy Ghost hath made you overseers, to feed the church of God, which he hath purchased with his own blood." Pastors are called by God to be shepherds of the church of God (Acts 20:28). They are not called to "do a job" or even to carry out "professional responsibilities," but are beckoned into a living, personal relationship with a community of people on behalf of Our Lord Jesus Christ. Pastoral ministry is then in essence, a very personal relationship.

Pastoral carers' need to continue working towards the losing of an impediment of those who have fallen in order to enhance them into a new Christianity life. Tidball (2009:194) argued that a pastor needed a spiritual maturity and a seeking of godliness and spiritual lives that grew not 'cold' for the flock but 'hot' also then restoring spiritual discipline toothers. Spiritual discipline is a major issue for the church members and a pastor has a duty to be spiritually consistent towards his flock. Pastoral care has been evolving during the ages and has more improvements that divulge the tremendous spiritual dimensions for the spiritual office, and it additionally deals with the spiritual temptations tp which pastors are vulnerable. It also also empowers a pastor to face the spiritual conflicts that endure and provide the needed spiritual resources. Baxter argued that visiting people is the principle method of bringing about personal "reformation" in a parish. Baxter's fundamental belief that personal visitation fortifies the total pastoral ministry can still be adapted to the contemporary church. This is particularly true in smaller communities where there are small neighborhood parishes.

Thus, the writings of the Reformers are examples to us today as we too attempt to live out the gospel and advance Christ's kingdom in a fallen and broken world. We dare not fail to learn from their successes and failures as we provide pastor care.

\section{e) The Evangelical Revival}

John Wesley (1703 - 1791 CE was an English minister, theologian, and evangelist, who was a leader of a huge revival movement within the Church of England called Methodism. 
Wesley was first and foremost a highly practical theologian and he was familiar with the importance of the relationship of theology with the practice of a ministry. Wesley fought against the detachment between theology and practice.

Wesley pastored his people and he modelled pastoral features in his own preaching and predominantly in his letter writing. Wesley wrote over three thousand letters to stressed parishioners (Heitzenrater, 1995). He encouraged people to make confessions on paper and his famous "Address to Clergy" written in 1754 was profound in its understanding of pastoral care. He stated to the clergy: "Let it not be imputed to forwardness, vanity, or presumption, that one who is of little esteem in the Church takes upon him thus to address a body of people, to many of whom he owes the highest reverence. I owe a still higher regard to Him who I believe requires this at my hands" (Maddox, 1994). He believed that good Pastors need to be overseers of the church and they should "naturally" display good understanding, have a clear apprehension and sound judgment, and above all a capacity for reasoning. They also require a sound knowledge of the office of a minister and the Holy Scriptures. Wesley believed that pastors had a huge role to play in life 9Thomas, 1994, Maddox, 1998).

Tidball (2009: 203) says that John Wesley wrote to his brother Charles Wesley that their business is to save souls. Moreover he stated that they not only to bring souls to believe in Christ but also to help mold or form them up in their utmost holy faith. This period was the period of pastoral care as deeply looking at the insights of a person. During the time of evangelical revival, pastoral care was very important as Wesley brothers were so keen in caring for the souls of people. The ministry of pastoral care had as its core business the idea of caring for souls. The Methodists use the structure that is called a 'class meeting' where people 'pour out their insights' to one another and the spiritual psycho-therapy starts for healing the wounds of others. Every leader of a class meeting is obliged to care for the members that are under his/her class. Therefore class leaders have to carry the burdens of the members and members carry each other's burdens as well.

During the period of John Wesley, pastoral care stretched to other mainline churches because it increased the pastoral work that ended up as an effective spiritual growth for church members. Tidball (2009: 208) stated that pastoral leadership increased formally like any other ecclesiastical ministry and had achieved far wider implications than for only Methodists.

\section{f) The 20th century and beyond}

In the twentieth century pastoral care was addressed by a Presbyterian minister whose name was Hiltner. He was ordained in 1935 (Tidball, 2009: 224). He asserts:

But I find it difficult to see how any theology we have can be vital unless it is constantly renewed by reflection on such experiences as have been described here. One reason why the very term "theology" seems so forbidding to the man in the street is precisely because theologians have not shown often enough that it is to actual human experiences of sin and redemption, meaninglessness and creation, that they look for their understanding of theology. I have put theological understanding into the category of things we can "get" from pastoral care. Perhaps the reason for this is now clearer. If we too are wayfarers on the journey and, no less than the alcoholic, will be progressively saved only as God's guidance becomes more real in our own lives, then it is as vital to us as to any man that our receptivity be increased, that our knowledge of God's ways with man be constantly growing and becoming more accurate. There is a revelation for us also not alone in the Scriptures, but also in the experience even of the alcoholic. (Hiltner, 1954). 
Van Arkel (2000: 143-160) recorded the major developments in the field of pastoral care as well as pastoral theology in the decade leading up to the year 2000. In his thinking the vital convictions that pastoral care has extended to the stage where it is essential to detect pastoral work. Pastoral care is the stage that building up the church from end to end discourses on caring achievement.

Gerkin (1997) and Heitink (1993) have wisely defined the developments in pastoral care from the $20^{\text {th }}$ century to the 21 st century. There are different approaches among pastoral care practitioners on their theological discourses due to the developments of pastoral care. Pastoral care developed more in the African continent during the $20^{\text {th }}$ and $21^{\text {st }}$ century. Gerkin (1997:76) advised that in our time, pastoral caregivers should be more skillful interpreters. The pastoral caregivers ought to interpret the biblical and Christian language and moreover its method of seeing and appraising the realm of people and their concerns as a directive to figure out their ordinary lives. The ministerial practice within the context of pastoral care is its diversity in its nature. The ministers (pastoral Practitioners) and church leaders providing pastoral care at the forefront of their ministry must be the pillars in caring. The church happens for the world since God first and supremely exists for the world, the church is to exist for others not self-service and pastoral care is critically important in this context. The proselytizing magnetism of the church is not subsidiary but rather critical to its existence as 'the people of God' (Nicolaides, 2010; Dayringer, 1995; Schwartz, 1991).

\section{g) The diverse patterns of the evolution}

Bossuyt and Milinkovitch (2000) have argued that convergent evolution, divergent evolution, parallel evolution and coevolution are the diverse patterns of evolution. Therefore convergent evolution will be the first to be explained.

Divergent evolution is the process in which a trait held by a common ancestor evolves into different variations over time (Bossuyt and Milinkovitch, 2000).

Coevolution occurs when closely interacting species exert selective pressures on each other, so that they evolve together in a kind of conversation of adaptations and they gave examples on among predator-prey and host-parasite pairs (Bossuyt \& Milinkovitch, 2000). It is in like fashion that pastoral care has evolved.

\section{h) New directions in pastoral care}

Blackburn (1975) and Hamblin (1978) made important contributions to people's ideas and practice of pastoral care. Furthermore in the 1970s, the first appraisals of pastoral care were published. Ribbins (1977) and Lang (1977) drew attention to a number of problems about pastoral care and there was a lack of clarity regarding its meaning, and it was used as a means of control and an emphasis was placed on structure of the expense of needed practices. In reflecting the current concerns of pastoral care in offering some important indications for the future, there are muchneeded aspects required to empower pastors and allow provision for the present and future needs of societies.

Pastoral care does not cease stop during a pandemic crisis and care is in many ways more critical than before. Pastoral care, and care for others is indispensable during things like the current Covid-19 pandemic. Many people are confronting depression, anxiety, and experience a huge sense of loneliness and all need care. Pastors should be a calming force in the storms of life. The pastor who cares should be teaching "...the Lord is my light and my salvation — whom shall I fear? The Lord is the stronghold of my life - of whom shall I be afraid?" (Psalms 27:1). In the 
middle of severe panic, a pastor's tranquil and steady presence needs to reflect Jesus and the safety we have in Him as our Lord and Saviour.

The new directions in pastoral care place an emphasis on the pastoral care for schools as the most vulnerable people are children in our current global context. Pastoral care reflects the growing amount of good and innovative practice and encourages innovation and development within schools (Watkins, 2017: xii). The entitlement of children to be valued, supported and developed as whole persons is at the heart of the work of the pastoral carer. Siwa (2018:3) stated that the notion of a child in the center of thinking was unthinkable as al need support. However, by putting the child in the center, Jesus forced the disciples to think the unthinkable! He turned their very beliefs about children upside-down. This teaching tells us that the youth and children are not a para-church but are to be at the center of everything that is indeed the church. The care of children cannot just be relegated to the work of the Youth Unit, but should be the work of the whole church body. Today, children are precious to every family irrespective of circumstances which sometimes militate against such appreciation. Parents sacrifice a lot to ensure that their children have a stake in what the world economies have to offer (Siwa, 2018: 3). The ministry of children is thus derived from what Jesus said "let the children come to me and do not hinder them" (Mathew 19:14). Siwa (2018: 4) furthermore stated that there are also many challenges when it comes to raising children to be upright and ethical persons.

\section{Conclusion}

As the name suggests, 'pastoral' care initially was an image related to shepherds and their flocks. In the Bible the image was readily understood. The shepherd, like David, knew his sheep by name and was ready to risk his life to protect the whole flock. In John's gospel Jesus is identified as the good shepherd who lays his life down for the sheep (John 10:11). In the same way ministers, priests and pastors are to deliver headship and care for their parishioners. They are to represent Christ to others as far as possible. The needed spiritual direction in ministry is vital but in the current era it is been pushed to the fringe of pastoral care.

As pastoral care is concerned with the curing and caring of souls of other people, the pastor himself also needs pastoral care because he is a human being even though he is set apart for this kind of a ministry. The power he received from God assists the pastor to help in carrying the burdens of others. For the Christian pastor, the gospel should animate his life, making him a person profoundly anxious for and carefully conscious of those around him. Pastoral care is hugely relevant these days because young people are not ashamed to harm another person through social media and many victims require help. They require well-conceived pastoral care therapy to ride out the 'storms of life'. Pastors needs to apply Christian faith and teaching in some way or other to the tangible situations of life facing parishioners and the community at large. Ministers need to be more intentional in their actions as well as responsive to the human needs of parishioners. Pastoral care should invariably become part of the life of a church group as they share expectations and anxieties with one another. The author notes with unpretentiousness that many areas have not been covered in this short study. There are many possible areas for future research on this important theme such as how diverse denominational belief systems view pastoral care such as the Orthodox, Anglican and Roman Catholics.

\section{References}

Arnold, B.M. (2012). Shepherding a Flock of a Different Fleece: A Historical and Social Analysis of the Unique Attributes of the African American Pastoral Caregiver. The Journal of Pastoral Care and Counseling,66(2), June 2012. 
Baxter, R. (1974). The Reformed Pastor, 1656, Edinburgh' Banner of Truth Trust.

Best, R., Lang, P., Lodge, C. \& Watkins, C. (Eds.), (2017). Pastoral Care and Personal-Social Education, Journal of Guidance and Counselling, 27(1), 71-84 University of London: Institute of Education.

Blackburn, K. (1975). The tutor. London: Heinemann.

Black, J.W. (2001). From Martin Bucer to Richard Baxter: "Discipline" and Reformation in Sixteenth and Seventeenth-Century England. American Society of Church History. Volume 70, pp. 644-673. https://doi.org/10.2307/3654544

Bossuyt, F. \& Milinkovitch, M.C. (2000). Convergent adaptive radiations in Madagascan and Asian ranid frogs reveal covariation between larval and adult traits. Proceedings of the National Academy of Sciences of the United States of America, 97: 6585-6590.

Breed, G. \& Semenya, K. (2015). Ubuntu, koinonia and diakonia, a way to reconciliation in South Africa?. HTS Theological Studies, 71(2), https://dx.doi.org/10.4102/hts.v71i2.2979

Bucer, M. (2009). Concerning the True Care of Souls, trans. Peter Beale, Carlisle, PA: Banner of Truth.

Campbell, V.A. (1987). A Dictionary of Pastoral Care. London: British Library Cataloguing in Publication Data.

Cartright, J. (1953). Evolution and Human Behavior: Darwinian perspective on human nature. Mendam: Library of Congress Cataloging-in-Publication Data.

Clebsch, W.A. \& Jaekle, C.R. (1967). Pastoral Care in Historical Perspective. New York: Harper.

Cooper, T.D. \& Randall, R.L. (2012). Grace for the Injured Self: Healing Approach of Heinz Kohut. Cambridge: The Lutterworth Press.

Dayringer R. (1995). The Heart of Pastoral Counselling, The Haworth Pastoral Press, New York. Gerkin, C.V. (1997). An introduction to pastoral care. Nashville: Abingdon Press.

Gonzalez, J.L. (2010). The Story of Christianity, Vol. 1. HarperOne, 2010.

Hamblin, D. (1978). The teacher and pastoral care. Oxford: Blackwell.

Heitink, G. (1993). Practical theology. History, theory action domains: Manual for practical theology. Transl. R. Bruinsma, W.B. Eerdmans Publishing Company, Grand Rapids, MI.

Heitzenrater, R. (1995). Wesley and the People Called Methodists. Nashville: Abingdon Press, Langford/

Hiestand, G. \& Wilson, T. (2015). The Pastor Theologian. Zondervan, 2015.

Hiltner, S. (1954). What we get and give in Pastoral care. Pastoral Psychology, 5, 14-25. https://doi.org/10.1007/BF01565036

Lartey, E.Y. (2003). In Living Color: An Intercultural Approach to Pastoral Care and Counseling $2^{\text {nd }}$ edition. Jessica Kingsley Publishers: EBook Pub. 
Louw, D.J. (2011). 'Philosophical counseling: Towards a "new approach" in pastoral care and counseling?'. HTS Teologiese Studies/Theological Studies, 67(2), doi:10.4102/hts.v67i2.900.

Maddox, R.L. (1994). Responsible Grace: John Wesley’s Practical Theology, Nashville: Abingdon Press.

Maddox, R.L.. (1998). ed. Rethinking Wesley's Theology for Contemporary Methodism, Nashville: Kingswood Books.

Martin Luther. (1994). "Ministers," in What Luther Says: A Practical In-Home Anthology for the Active Christian (ed. Ewald M. Plass; 1959; Saint Louis, MO: Concordia, 932.

Moorhead, J. (2005). Gregory the Great. Routledge, 2005.

Nicolaides, A. (2010). The Laos tou Theou - an orthodox view of the "people of God", HTS Teologiese Studies/Theological Studies, 66(1), DOI: 10.4102/hts.v66i1.372

Nicolaides, A. (2005). Ubuntu promoting ethical business conducts in African Society. Orthodox and the great social and economic problems of Africa: The contribution of the great monotheistic to their solution, paper presented at the International Interparliamentary Assembly on Orthodoxy Conference, University of Johannesburg, 02 December, 2015.

Nouwen, H. (2006). Spiritual Direction, San Francisco, Harper One,

Schwartz, D.B. (1991). Who Cares, Rediscovering Community, Westview Press, United Kingdom.

Sifo, L.G. \& Masango, M.J. (2014). 'The impact of spousal violence on the children: A pastoral care approach'. HTS Teologiese Studies/Theological Studies, 70(2), http://dx.doi.org/10.4102/hts. v70i2.2044.

Stephens, W. P. (1986). The Theology of Huldrych Zwingli, Oxford: Clarendon Press.

St. Gregory the Great. (2012). The Rule for Pastors (Pastoral Care). Wyatt North.

Themelios (n.d.) The Care of Souls: The Heart of the Reformation, Themelios, 39(1).Available online at https://www.thegospelcoalition.org/themelios/article/the-care-of-souls-the-heart-of-thereformation/

Thomas A. (1984). Practical Divinity: Theology in the Wesleyan Tradition. Nashville: Abingdon Press, 1984.

Tidball, D. (2009). Skillful Shepherds Explorations in Pastoral Theology. New York: Input Typesetting.

Ungvarsky, J. (2018). Pastoral care: Spiritual healing Faith (Christianity). Salem Press Encyclopedia of Health. http://0-search.ebscohost.com.wam.seals.ac.za

Van Arkel, J.D.J. (2000). 'Recent movements in pastoral theology'. Religion and Theology, 7, 142167. http://dx.doi.org/10.1163/157430100X00351 